\title{
Determining groundwater facies and water quality index in Tanah Bumbu Regency/South Borneo Indonesia
}

\author{
Thomas Triadi Putranto*, and Rahmad S. Ginting \\ Geological Engineering Department, Diponegoro University, 50275 Semarang, Indonesia
}

\begin{abstract}
Most people in Tanah Bumbu Regency use water from dug wells for their daily activities. Kotabaru Regency is located in Pagatan Groundwater Basin, which is located in three administrative boundaries, namely Tanah Laut Regency, Tanah Bumbu Regency, The purposes of this study are to determine the type of groundwater facies and Water Quality Index (WQI). The methods were hydrogeological mapping and hydrogeochemical analysis of groundwater samples to evaluate groundwater quality. There were 170 groundwater samples mapped in the study area. The study area has differences in groundwater quality in both confined aquifer and unconfined aquifer. The unconfined aquifer has two types of groundwater facies, namely $\mathrm{Ca}-\mathrm{Mg}-\mathrm{HCO}_{3}$ (Calcium Magnesium Bicarbonate) and $\mathrm{Ca}-\mathrm{Cl}$ (Calcium Chloride). In comparison, the confined aquifer has two types, which are $\mathrm{Ca}-\mathrm{Mg}-\mathrm{HCO}_{3^{-}}$(Calcium Magnesium Bicarbonate) and $\mathrm{Na}-\mathrm{HCO}_{3}-$ (Sodium Bicarbonate). Based on the calculation of the Water Quality Index (WQI) of unconfined aquifer samples show that $70 \%$ of groundwater samples have poor quality. Meanwhile, the confined aquifer samples indicate that $85 \%$ of groundwater samples have good to excellent, which is suitable for drinking water.
\end{abstract}

\section{Introduction}

Tanah Bumbu Regency is part of the Pagatan Groundwater Basin which is a cross-regency groundwater basin covering Tanah Laut Regency, Tanah Bumbu Regency and Kotabaru Regency [1].

The Pagatan groundwater basin in Tanah Bumbu Regency has an area of $5,067 \mathrm{~km}^{2}$ (506,714 ha) or $13.50 \%$ of the total area of South Kalimantan Province which consists of ten sub-districts (Figure 1a). In 2019, the population of Tanah Bumbu Regency was 320,452 inhabitants [2]. Most people in Tanah Bumbu Regency withdrawn groundwater via dug wells for daily activities. Therefore, it is necessary to conduct a study regarding the quality of groundwater both groundwater from the unconfined aquifer and confined aquifer to determine the groundwater facies and Water Quality Index (WQI) as the goals of this research. Analysis of hydrogeochemistry and WQI is widely developed recently by some researchers to assess groundwater quality for defining the groundwater facies and a rating

* Corresponding author: putranto@ft.undip.ac.id 
which are reflecting the composite influence of different water quality parameters on the overall quality of water [4-8].

Tanah Bumbu Regency is included in the Kotabaru [3] and the Banjarmasin regional geological map sheets [12] (Figure 1b). Based on the geological map, it can be seen that the geological conditions of the study area are dominated by sedimentary rock types. Lithostratigraphically, the type of rock in the study area from the oldest to the youngest, namely as follows:

- Ultramafic (Mub) Rock Formation: consists of basaltic igneous rocks such as serpentinite, gabbro, basalt, harzburgite, durite, and concentrated pyroxenite. This formation is spread north of Tanah Bumbu Regency spread locally on one hill in Simpang Empat District.

- Tanjung (Tet) Formation: consists of interlocking claystone, sandstone, breccia with shale, coal, and limestone inserts. Tanjung Formation spreads on a higher plane in the hilly area of North Tanah Bumbu and along the northwest of Tanah Bumbu Regency. Tanjung Formation can be found in Batulicin District, Karang Bintang, Kusan Raya, and Satui.

- Berai (Tomb) Formation: consist of clastic limestones and has an early OligoceneMiocene age. Berai Formation can be found in Kuranji, Kusan Hilir, Kusan Hulu, Kusan Raya, Central Kusan, Batulicin, Simpang Empat, Karang Bintang, Mentewe and Satui.

- Warukin Formation (Tmw): consists of interlocking units of quartz sandstone and easily crushed claystone, locally inserts shale, coal and limestone. Warukin Formation spreads in the southern area of Tanah Bumbu Regency. Warukin formations can be found in the Loban, Kuranji, Kusan Hilir, Kusan Raya, and Satui Districts.

- Dahor Formation consists of a perishable quartz sandstone unit, locally insulated with clay, lignite, limonite, glaucous, quartz, Pliocene-Pleistocene. The Dahor Formation is spread in the southern area of Tanah Bumbu Regency, close to the sea, in relatively sloping morphology. The Dahor Formation can be found in the Districts of Loban River, Angsana, and Satui.

- Alluvium deposits occupy in coastal plains, rivers and swamps. Alluvium deposits consist of gravel to clay and the rest of the plant. Alluvium spreads in areas close to the sea in the southern area of Tanah Bumbu Regency, namely in Kusan Hilir, Kusan Hulu, Angsana, Satui and Loban Rivers.

According to [13], the groundwater potency in Pagatan groundwater basin can be classified into two. Aquifer with the depth up to $30 \mathrm{~m}$ depth is only feasible for household activities with a maximum discharge of $100 \mathrm{~m}^{3} / \mathrm{month} /$ well. While aquifer with the depth of more than $30 \mathrm{~m}$ depth is categorized with a low potential is limited to a maximum of $540 \mathrm{~m}^{3} /$ day/well. There are two types of aquifers in the study area, as follows:

1. Groundwater which flows in the lowland aquifer system

Generally occupying in the western, the southern, the eastern, and locally in the coastal areas, in the flood plain and inter-hill/mountain plain. The rocks consist of loose material such as clay, sand and gravel; Groundwater flow takes place through a space between granular aquifer systems. The aquifer system generally shows the unconfined aquifer.

2. Karst Aquifer System

It is a typical morphological appearance of limestone hills which is characterized by the presence of fissures, fractures, and dissolution channels. 

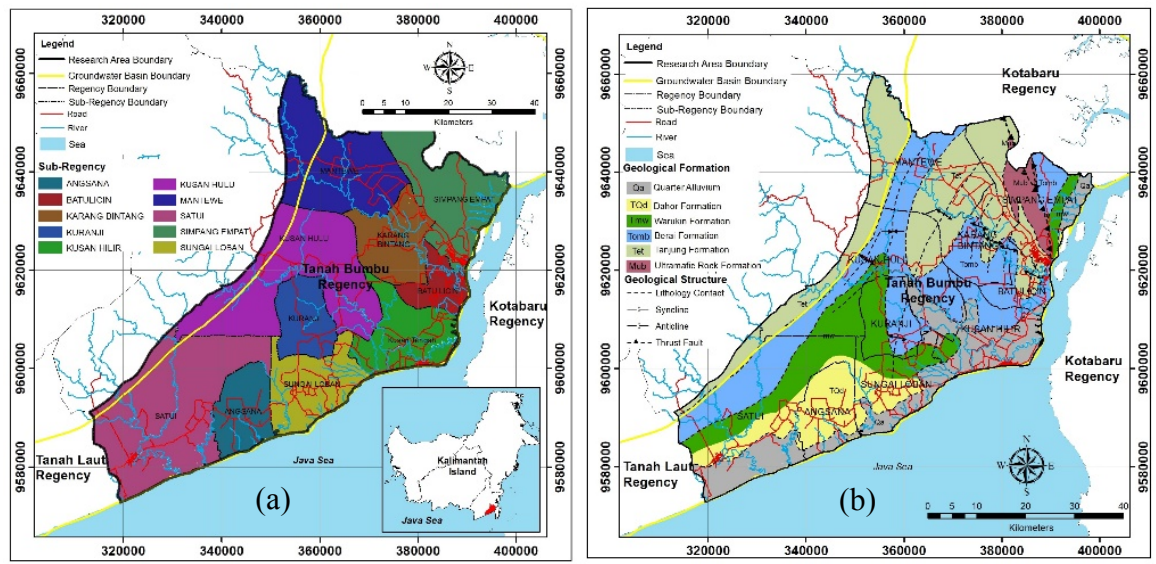

Fig. 1. Pagatan groundwater basin in the Tanah Bumbu Regency (a) the regional geological map (b)

\section{Methods}

The activities in the field campaign were geological and hydrogeological mapping, respectively. Geomorphology and surface geological mapping was the activities in the geological mapping. Groundwater level measurement in the dug wells and groundwater sampling were the main activities in hydrogeological mapping. There were 170 samples taken to analyze $\mathrm{pH}$ and $\mathrm{EC}$ values. While 30 of them were tested in hydrogeochemical for both major cations $\left(\mathrm{Ca}^{2+}, \mathrm{Mg}^{2+}, \mathrm{K}^{+}\right.$, and $\left.\mathrm{Na}^{+}\right)$, and anions $\left(\mathrm{HCO}_{3}{ }^{-}, \mathrm{Cl}^{-}\right.$, and $\left.\mathrm{SO}_{4}{ }^{2-}\right)$ content in the laboratory of Geological Agency in Bandung. A Piper diagram [14] was applied to define the groundwater facies. [6] developed a practical graphic procedure to separate relevant analytical data from comprehending the sources of the dissolved constituents in groundwater. This procedure was developed under the proclamation that most natural groundwater contains major cations and anions in chemical equilibrium. It is affected that the most abundant cations are two alkaline earth calcium $\left(\mathrm{Ca}^{2+}\right)$ and magnesium $\left(\mathrm{Mg}^{2+}\right)$ and one Alkali sodium $\left(\mathrm{Na}^{+}\right)$. The most major anions are one weak acid bicarbonate $\left(\mathrm{HCO}_{3}{ }^{-}\right)$and two strong acids, sulfate $\left(\mathrm{SO}_{4}{ }^{2-}\right)$ and chloride $\left(\mathrm{Cl}^{-}\right)$.

Weighting groundwater quality based on the Water Quality Index (WQI) [11] can be approached to evaluate the quality of groundwater in its use as drinking water. Each parameter is determined according to its effect on health. The relative weight value (Wi) is obtained from Equation 1 as follows:

$$
\begin{aligned}
& W i=\frac{w i}{\sum_{i=1}^{n} w i} \\
& q i=\frac{C i}{S i} \times 100 \\
& \mathrm{SI}=\mathrm{Wi} \times \mathrm{qi} \\
& \mathrm{WQI}=\sum \mathrm{SI}
\end{aligned}
$$

Whereas Wi was the relative weight value given to each parameter, and $\mathrm{n}$ is the number of parameters. Next was calculating the quality rating scale (qi) for each predetermined parameter. The qi value was obtained from the comparison of the specified parameter value 
(Ci) to the specified standard value ( $\mathrm{Si}$ ), as shown in Eq. 2. The standard value for each parameter used was the maximum value of each parameter based on the Minister of Health Regulation [15] for the water drinking standard. The Sub Index (SI) value was calculated by multiplication between relative weight and the rating scale values. Then, the WQI was conducted by the total value of the Sub Index (SI). The range of WQI was shown in table 1. The parameters to assess WQI for the unconfined aquifer were color, turbidity, $\mathrm{pH}$, and $\mathrm{Fe}^{3+}$. Furthermore, the WQI for confined aquifer were calculated based on color, turbidity, $\mathrm{Fe}^{3+}$, $\mathrm{Na}^{2+}$, and Total Dissolved Solids/TDS values.

Table 1. Water quality index (WQI) range

\begin{tabular}{ll}
\hline Water Quality Index Range & Quality \\
\hline$<50$ & Excellent \\
$50-100$ & Good \\
$100-200$ & Poor \\
$200-300$ & Very Poor \\
$>300$ & Unfeasible for drinking water \\
\hline
\end{tabular}

\section{Results and Discussion}

\subsection{Groundwater flow direction}

Based on the hydrogeological mapping, in the unconfined aquifer groundwater flow towards the east or the Java Sea. The direction of the groundwater flow pattern follows the topographic, which tends to be lower to the east (Figure 2a). The groundwater level of an unconfined aquifer is at an elevation $0.7-49 \mathrm{~m}$ above sea level (masl) with a depth of the water table is from 0.1 to $7.7 \mathrm{~m}$ depth below ground surface. The intensive groundwater used via dug wells is depicted by the very dense presence of dug wells.

Meanwhile, the pattern of groundwater flow of the confined aquifer has a pattern relatively similar to the flow direction of the unconfined aquifer, which flows to the east (Figure 2b), but different in the number of deep wells in the study area. Mainly, groundwater used both via dug, and deep wells are utilized for daily activities.
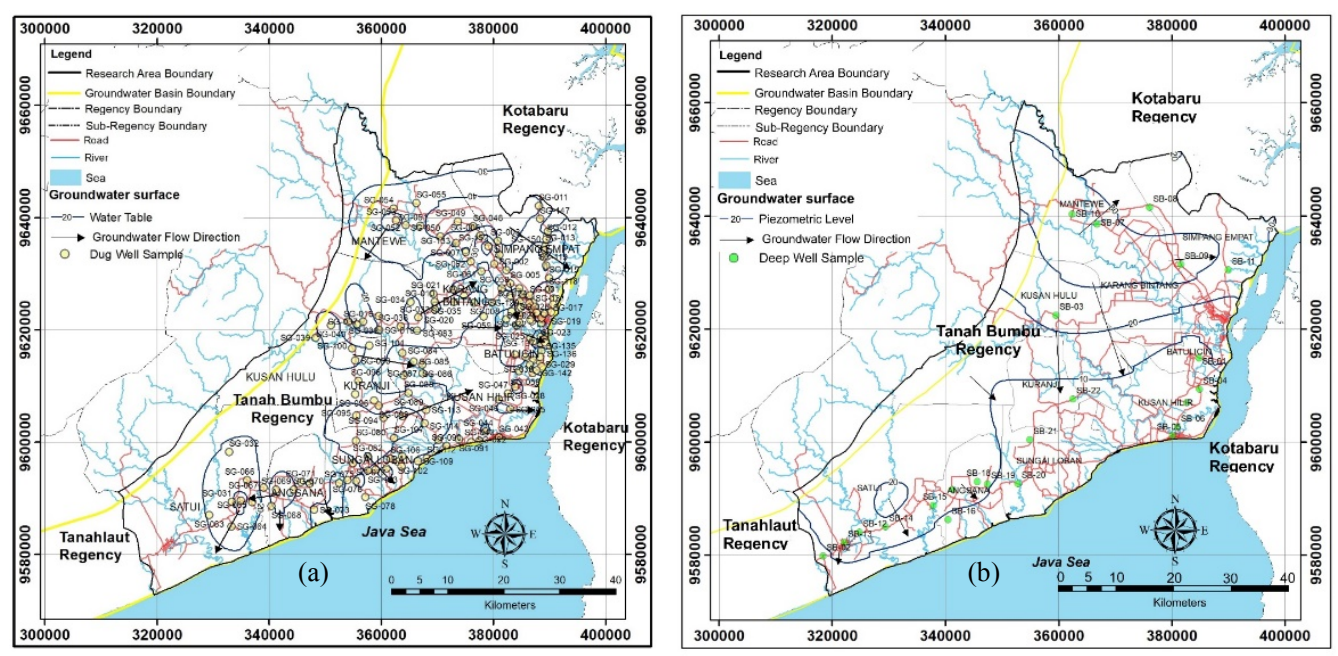

Fig. 2. Groundwater level and its direction of the unconfined aquifer (a) and the confined aquifer (b). 


\subsection{Hydrogeochemistry}

There are thirty groundwater samples that are analyzed physical and chemical content in the Geological Agency laboratory in Bandung, as shown in Table 2. Twenty of them are selected from the confined aquifer samples (code: SB), while the rest are samples of the unconfined aquifer (code: $\mathrm{SG}$ ).

Based on table 2, there are five samples of the confined aquifer exceed the limit standard of turbidity from the Indonesian Ministry of Health, 5 NTU, while the unconfined aquifer samples are seven. Enormous numbers higher of turbidity values in the unconfined aquifer are due to the poor quality of dug wells construction in Tanah Bumbu Regency. Many dug wells are used the uncemented wall. Thus the rocks in the wall of dug well are mostly dissolved into the well. While the color parameter shows that groundwater samples from unconfined aquifers exceed the standard of water, $15 \mathrm{TCU}$, more than samples from unconfined aquifers, it reflects the contact intensity between water and rocks due to groundwater extraction through deep wells.

Meanwhile, the range of electrical conductivity of the unconfined aquifer is $20-405 \mu \mathrm{S} / \mathrm{cm}$. Indeed, the EC value of the confined aquifer has a variety of $44-1,507 \mu \mathrm{S} / \mathrm{cm}$. These values, both for the unconfined aquifer and the confined aquifer, are suitable for drinking water. Similar to the EC value, the TDS value of groundwater samples of the unconfined aquifer is $16-272 \mathrm{mg} / \mathrm{L}$, which indicates below the standard limit, $500 \mathrm{mg} / \mathrm{L}$. While the TDS value of groundwater samples from the confined aquifer show from 32 to $1,008 \mathrm{mg} / \mathrm{L}$, which indicates two-fold higher than the standard limit. The $\mathrm{pH}$ values of groundwater samples of the unconfined aquifer and confined aquifer are 3.89-7.16 and 4.438.40 , respectively. The low values of $\mathrm{pH}$ below the standard limit are caused by the dominance of peatlands, which are mostly found in acidic, thereby reducing the $\mathrm{pH}$ value of groundwater in the study area. Meanwhile, based on the total hardness of all groundwater samples indicate that water is classified as soft water with a maximum value of $327 \mathrm{mg} / \mathrm{L}$. The total hardness values are below the standard limit for drinking water, $500 \mathrm{mg} / \mathrm{L}$.

The major cation contents are Calcium $\left(\mathrm{Ca}^{2+}\right)$ and Sodium $\left(\mathrm{Na}^{+}\right)$, while Hydrogen carbonate $\left(\mathrm{HCO}_{3}{ }^{-}\right)$and $\mathrm{Chloride}\left(\mathrm{Cl}^{-}\right)$are the highest anions concentration in the groundwater samples both the unconfined aquifer and the confined aquifer. Water types of the confined aquifer are divided into two dominant groundwater facies, namely facies of $\mathrm{Ca}-\mathrm{Mg}-\mathrm{HCO}_{3}$ (Calcium Magnesium Bicarbonate) and facies of $\mathrm{Na}_{-} \mathrm{HCO}_{3}$ (Sodium Bicarbonate) as shown in Figure 3. Facies of Ca-Mg-HCO 3 indicate that water is associated with ions $\mathrm{Ca}^{2+}$ and $\mathrm{Mg}^{2+}$ from the carbonate minerals in sandstone and limestone units as well as from clay minerals in alluvium deposits and claystones. While $\mathrm{HCO}_{3}{ }^{-}$ion comes from surface water (meteoric water) where surface water experiences mixing with $\mathrm{CO}_{2}$ from the atmosphere, which then infiltrates into the soil. Facies of $\mathrm{Na}-\mathrm{HCO} 3$ where $\mathrm{Na}^{2+}$ ions are interpreted from rocks formed in the marine depositional conditions, rocks sediments and alluvium deposits.

Meanwhile, groundwater samples in the unconfined aquifers are divided into two dominant groundwater facies, namely facies of $\mathrm{Ca}-\mathrm{Mg}-\mathrm{HCO}_{3}$ (Calcium Magnesium Bicarbonate) and facies of $\mathrm{Ca}-\mathrm{Cl}$ (Calcium Chloride) as shown in Figure 4. Water type of $\mathrm{Ca}-\mathrm{Mg}-\mathrm{HCO}_{3}$ in the unconfined aquifer is similar to water type from the confined aquifer as a result of contact between sedimentary rocks and unconsolidated materials (from the carbonate minerals in sandstone, limestone claystone, and alluvial deposit). $\mathrm{Ca}-\mathrm{Cl}$ facies shows that the water comes from a mixture of groundwater associated with $\mathrm{Ca}^{2+}$ and $\mathrm{Mg}^{2+}$ ions from carbonate minerals in sandstone units, limestones, and clay minerals in alluvium deposits. $\mathrm{Cl}^{-}$ions are derived from the infiltration of seawater into the aquifer and sedimentary rocks that have marine depositional conditions. 
Table 2. The physical and chemical content of groundwater samples in Tanah Bumbu Regency

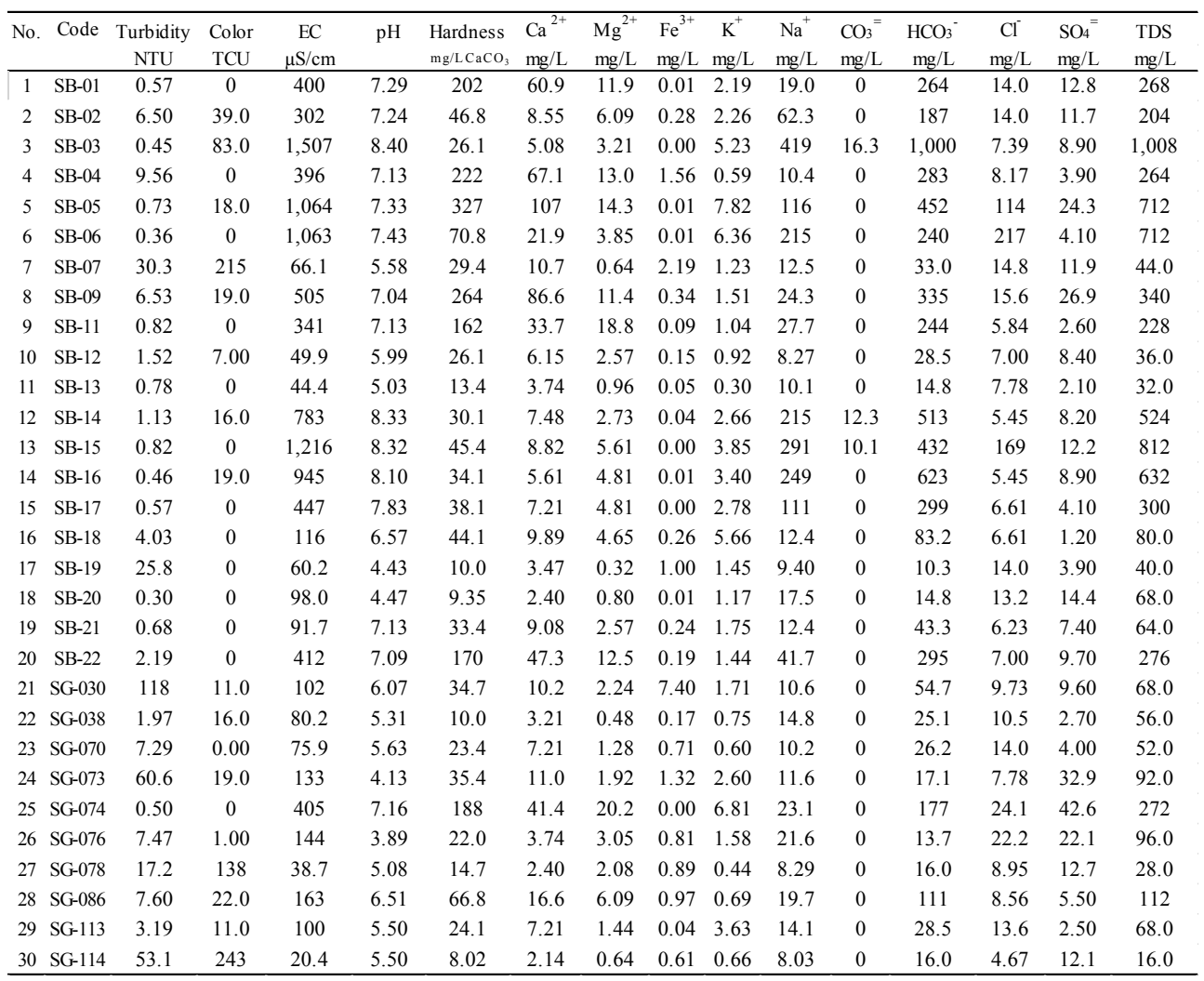

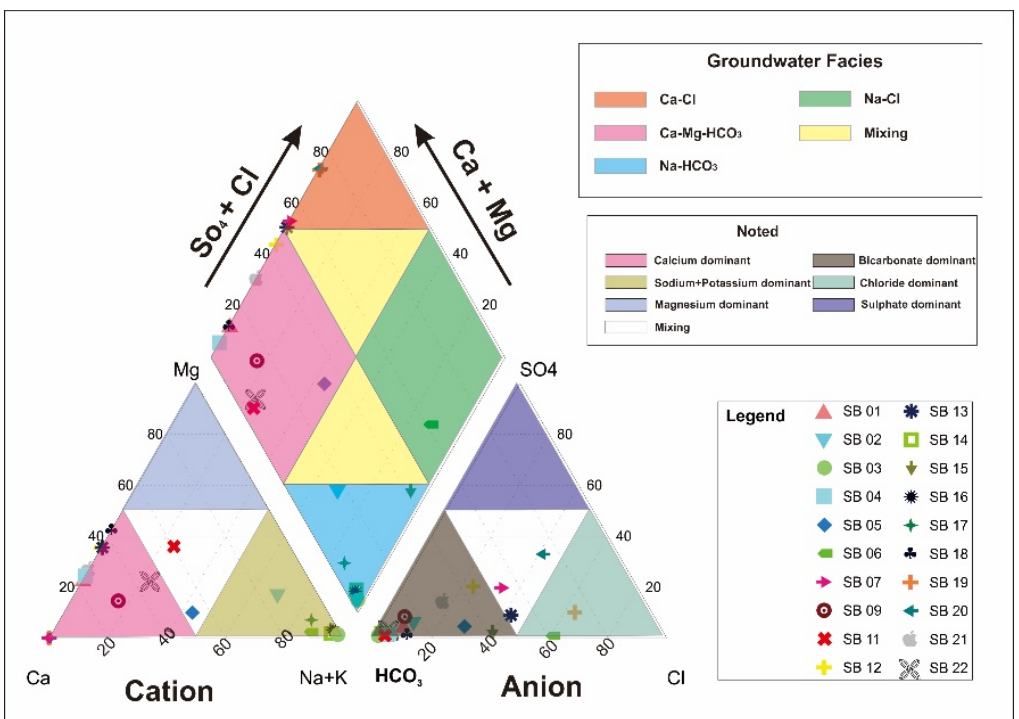

Fig. 3. Piper diagram showing water type of groundwater samples of the confined aquifer 


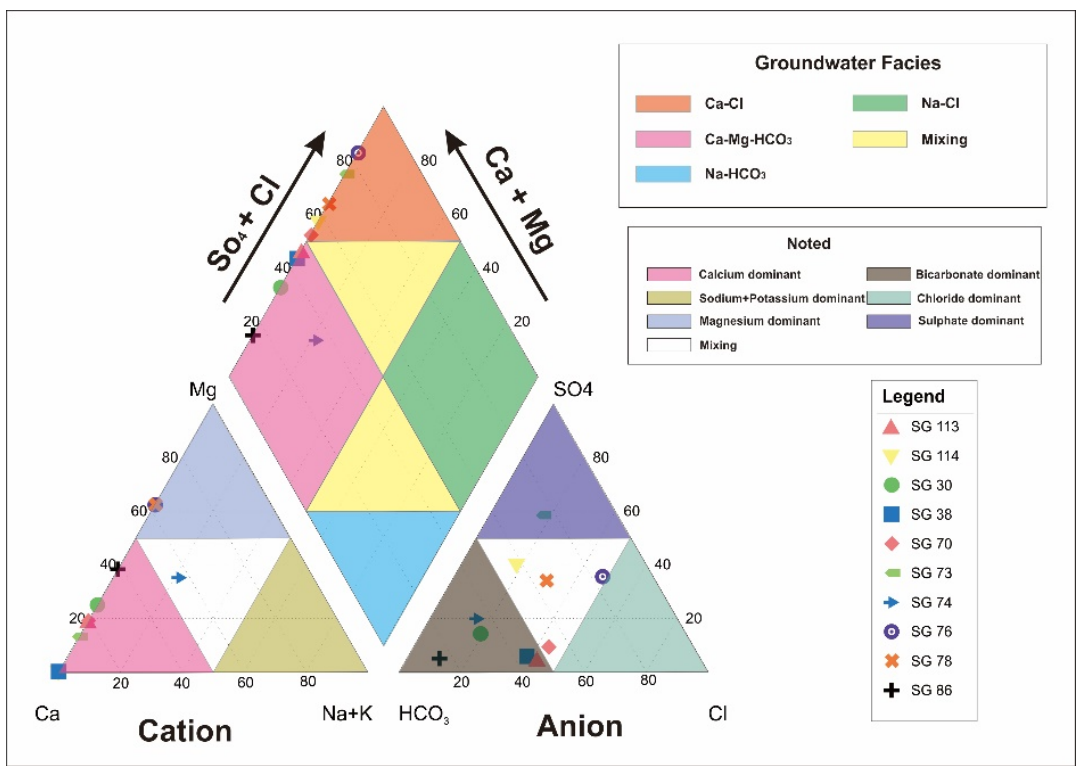

Fig. 4. Water-type of groundwater samples of the unconfined aquifer in the Piper diagram

\subsection{Water Quality Index (WQI)}

Parameters that are applied to calculate WQI for the confined aquifer samples are color, turbidity, $\mathrm{pH}, \mathrm{Fe}^{3+}, \mathrm{Na}^{+}$, and TDS, as shown in Table 3. Based on table 3 and equation 1-4, the WQI of the twenty groundwater samples of the confined aquifer results in five classes, as shown in Table 4. The calculation of the WQI obtains the minimum value of WQI, which is equal to 11.3 and a maximum value of 556 with an average value of 85.2. Good to excellent quality samples are up to $85 \%$ while the rest are poor to unfeasible for drinking water. Figure 5 shows the distribution of WQI groundwater samples of the confined aquifer. Good to excellent samples are mainly located in Quaternary alluvium aquifer while poor to unfeasible for drinking water samples consist of unconsolidated quartz sandstone intercalated with clay, limestone, and lignite.

Table 3. The relative weight of the parameter to calculate WQI in the confined aquifer

\begin{tabular}{lccc}
\hline Parameter & Standard limit $[15]$ & Weight $\left(\mathrm{w}_{\mathrm{i}}\right)$ & Relative weight (Wi) \\
\hline Color $(\mathrm{TCU})$ & 5 & 2 & 0.14 \\
Turbidity (NTU) & 15 & 4 & 0.29 \\
$\mathrm{pH}(-)$ & $6.5-8.5$ & 2 & 0.14 \\
$\mathrm{Fe}^{3+}(\mathrm{mg} / \mathrm{L})$ & 0.3 & 1 & 0.07 \\
$\mathrm{Na}^{+}(\mathrm{mg} / \mathrm{L})$ & 200 & 2 & 0.14 \\
$\mathrm{TDS}(\mathrm{mg} / \mathrm{L})$ & 500 & 3 & 0.21 \\
& & $\Sigma \mathrm{W}_{\mathrm{i}}=14$ & $\Sigma \mathrm{W}_{\mathrm{i}}=1.0$ \\
\hline
\end{tabular}


Table 4. WQI of groundwater samples of the confined aquifer

\begin{tabular}{llcl}
\hline WQI Scale & Quality & Distribution (\%) & Sample Code \\
\hline$<50$ & Excellent & 45 & SB-01, SB-11, SB-12, SB-13, \\
& & & SB-17, SB-18, SB-20, SB-21, \\
& & & SB-22 \\
$50-100$ & Good & 40 & SB-04, SB-05, SB-06, SB-09, \\
& & & SB-14, SB-15, SB-16, SB-19 \\
$100-200$ & Poor & 5 & SB-02 \\
$200-300$ & Very Poor & 5 & SB-03 \\
$>300$ & $\begin{array}{l}\text { Unfeasible for } \\
\text { drinking water }\end{array}$ & 5 & SB-07 \\
& & & \\
\hline
\end{tabular}

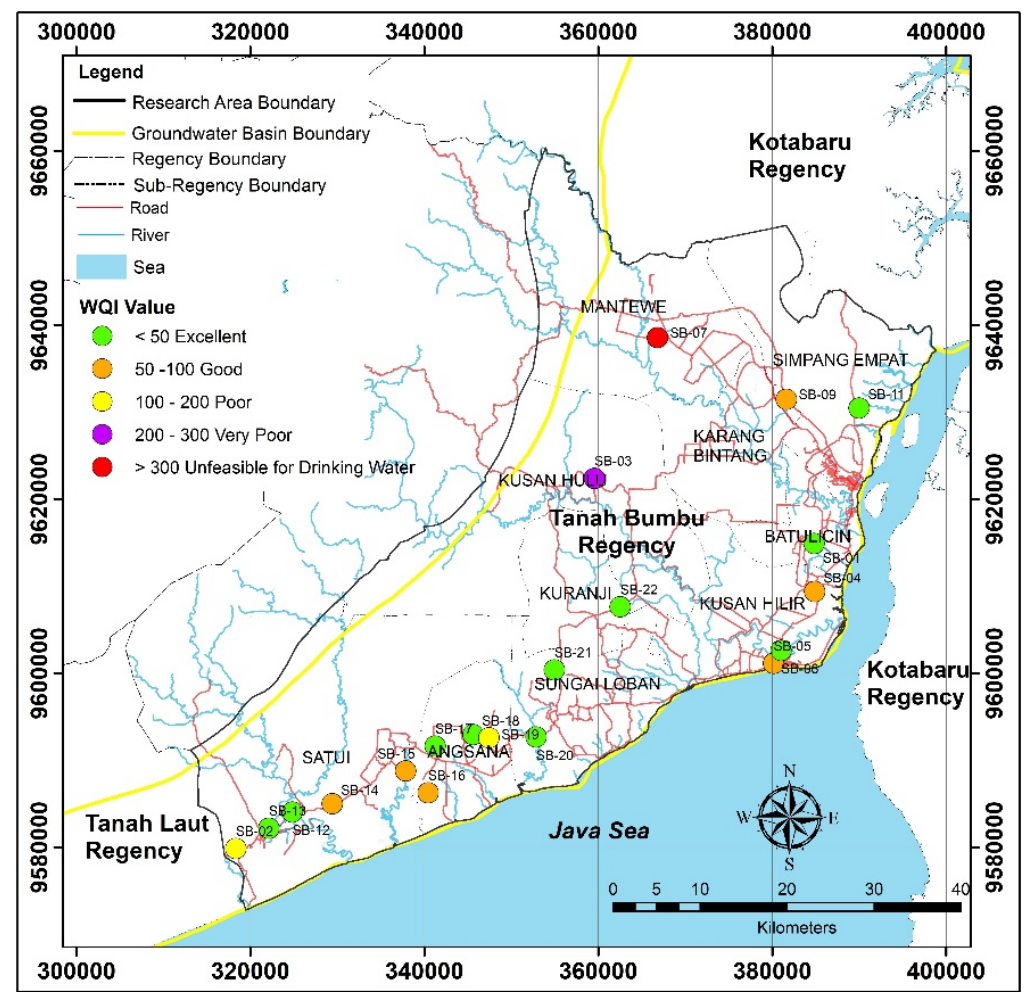

Fig. 5. WQI map of confined aquifer samples

Colour, turbidity, $\mathrm{pH}$, and $\mathrm{Fe}^{2+}$ are the parameters applied to calculate WQI for ten unconfined aquifer samples, as shown in Table 5. The WQI of the ten groundwater samples of the unconfined aquifer results in four classes, as shown in Table 5 with the range of WQI value is 7.36-1,398. There are four samples that have unfeasible for drinking water while another three samples have a very poor water quality index. The rest are good to excellent quality. Samples that have poor to unfeasible for drinking water are located along the coastline of the Java Sea. The aquifer consists of Quarternary alluvium. The lowest WQI, SG-114, is caused by the highest value of parameters turbidity, color, and $\mathrm{Fe}^{3+}$ due to the dug well of SG-114 has uncasing on the well. Thus the unconsolidated material such as clay, and clayey sand will be dissolved with groundwater. Moreover, SG-114 also contains low pH, 5.5 , as shown in Table 2 that is below the standard limit for drinking water. 
Table 5. Relative weight of the parameter to calculate WQI in the unconfined aquifer

\begin{tabular}{lccc}
\hline Parameter & Standard limit $[15]$ & Weight $\left(\mathrm{w}_{\mathrm{i}}\right)$ & Relative weight $(\mathrm{Wi})$ \\
\hline Color (TCU) & 5 & 4 & 0.28 \\
Turbidity (NTU) & 15 & 2 & 0.14 \\
$\mathrm{pH}(-)$ & $6.5-8.5$ & 4 & 0.29 \\
$\mathrm{Fe}^{3+}(\mathrm{mg} / \mathrm{L})$ & 0.3 & 4 & 0.29 \\
& & $\Sigma \mathrm{W}_{\mathrm{i}}=14$ & $\Sigma \mathrm{W}_{\mathrm{i}}=1.0$ \\
\hline
\end{tabular}

Table 6. WQI of groundwater samples of the unconfined aquifer

\begin{tabular}{clcl}
\hline WQI Scale & Quality & Distribution $(\%)$ & Sample Code \\
\hline$<50$ & Excellent & 20 & SG-74, SG-113 \\
$50-100$ & Good & 10 & SG-38 \\
$100-200$ & Poor & 30 & SG-70, SG-76, SG-86 \\
$200-300$ & Very Poor & 0 & - \\
$>300$ & Unfeasible for & 40 & SG-30, SG-73, SG78, SG-114 \\
& drinking water & & \\
\hline
\end{tabular}

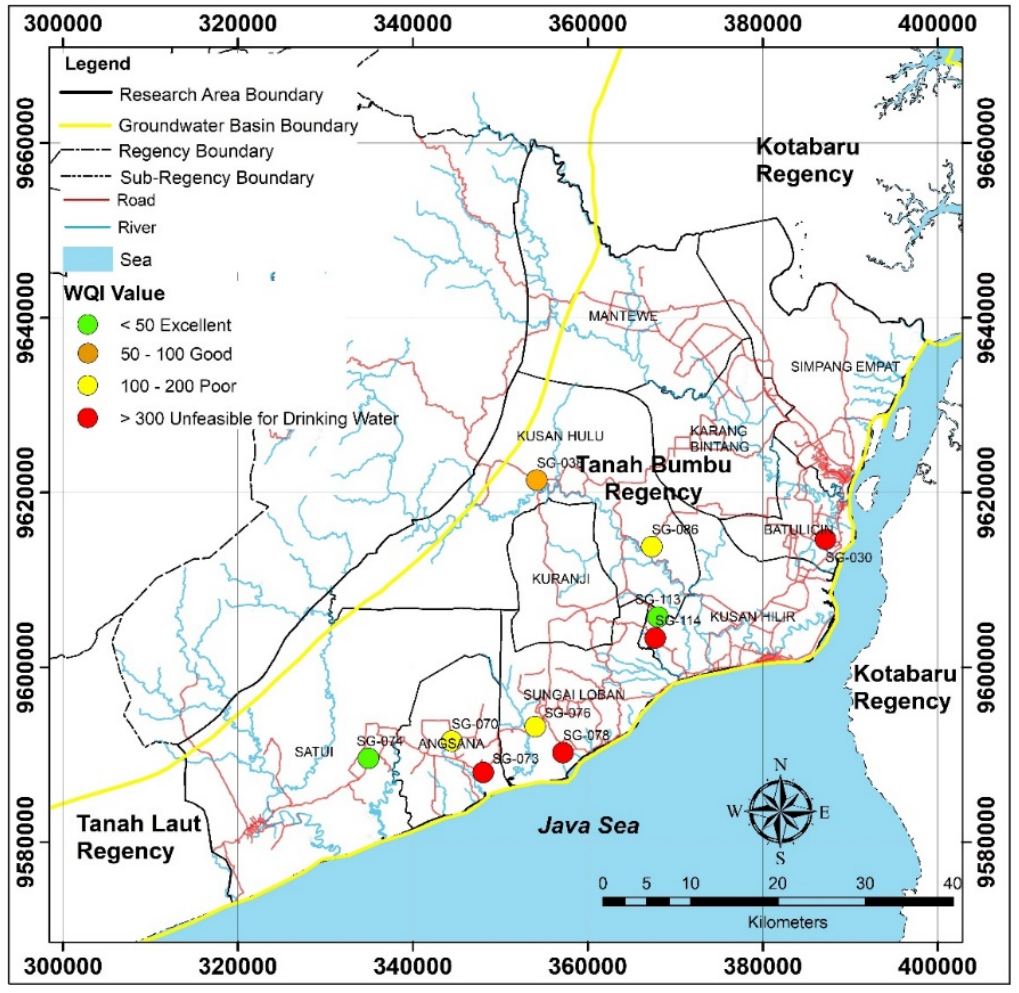

Fig. 6. WQI map of unconfined aquifer samples

\section{Conclusion}


Groundwater samples for both unconfined aquifer and confined aquifer define the groundwater facies which indicate particular character and chemistry. Water types of the confined aquifer are divided into two dominant groundwater facies, namely $\mathrm{Ca}-\mathrm{Mg}-\mathrm{HCO}_{3}$ (Calcium Magnesium Bicarbonate), and $\mathrm{Na}-\mathrm{HCO}_{3}$ (Sodium Bicarbonate). Facies of Ca-Mg$\mathrm{HCO}_{3}$ indicate that water is associated with ions $\mathrm{Ca}^{2+}$ and $\mathrm{Mg}^{2+}$ from the carbonate minerals of the aquifer content in sandstone and limestone units as well as from clay minerals in alluvium deposits and claystones. While $\mathrm{HCO}_{3}{ }^{-}$ion comes from surface water (meteoric water). Meanwhile, groundwater samples in the unconfined aquifers are divided into two dominant groundwater facies, namely $\mathrm{Ca}-\mathrm{Mg}-\mathrm{HCO}_{3}$ (Calcium Magnesium Bicarbonate) and $\mathrm{Ca}-\mathrm{Cl}$ (Calcium Chloride). Facies of $\mathrm{Ca}-\mathrm{Mg}-\mathrm{HCO}_{3}$ is a similar characteristic to the confined aquifer while $\mathrm{Ca}-\mathrm{Cl}$ facies shows that the water comes from a mixture of groundwater associated with carbonate minerals in sandstone units, limestones, and clay minerals in alluvium deposits. Moreover, $\mathrm{Cl}^{-}$ions are derived from the infiltration of seawater into the aquifer.

The WQI of the twenty groundwater samples of the confined aquifer results in five classes from unfeasible for drinking water to excellent in quality. The good to excellent groundwater quality samples are mainly located in Quaternary alluvium aquifer. Meanwhile, the poor to unfeasible for drinking water samples consist of unconsolidated quartz sandstone intercalated with clay, limestone, and lignite. The $85 \%$ of the confined aquifer samples are good to excellent in quality, while only $30 \%$ of the unconfined aquifer samples are suitable for drinking water.

\section{References}

1. Ministry of Energy and Mineral Resources the Republic of the Government of Indonesia, (2017)

2. Statistics of Tanah Bumbu Regency, (2020)

3. E. Rustandi, E.S. Nila, P. Sanyoto, U. Margono (1995)

4. A.K Batabyal, S. Chakraborty. J, Water Env Resc, 87, 7 (2015).

5. I. Mendizabal, P.J. Stuyfzand, A.P. Wiersma, Hydrog J, 19, 1 (2011)

6. J.A.R. Leal, C.N. Medrani, F.O.T Silva, J.T.S Garcia, L.R.R. Gutierrez, Hydrog J, 20, 3 (2012)

7. Rabeiy, R.E. Enc.S.P.R, 25,31 (2018)

8. El., Ander, M.J. Watts, P.L., Smedley, E.M. Hamilton, R. Close, H. Crabbe, T. Fletcher, A. Rimell, M. Studden, G. Leonardi, Env.GH, 38, 6 (2016)

9. J. Bian, S. Nie, R. Wang, H. Wand, C. Liu, Env MA, 190 (2018)

10. Z. Abbas, H.W.T Mapoma, C. Su, S.Z. Aziz, Y. Ma, N. Abbas, Env MA 190 (2018)

11. T. Akter, F.T. Jhohura, F. Akter, T.R. Chowdury, S.K. Mistry, D. Dey, M.K. Barua, M.A. Islam, M Rahman, 35, (2016)

12. N. Sikumbang, R. Heryanto, P3G (1994)

13. Sihwanto, Wahyudin, DGTL, (2005)

14. A.M. Piper, 25, 6, (1944)

15. Ministry of Health the Republic of the Government of Indonesia, (2010) 